\title{
PENGARUH KOMUNIKASI ORGANISASI, KECERDASAN EMOSI DAN PENGAMBILAN KEPUTUSAN TERHADAP IMPLEMENTASI PERAN KEPEMIMPINAN KEPALA SD
}

\author{
Budiono, Udik Budi Wibowo \\ SD Negeri 1 Wonosari, Universitas Negeri Yogyakarta \\ buditulada@gmail.com, yube2u@yahoo.com
}

\begin{abstract}
Abstrak
Penelitian ini bertujuan untuk mengetahui pengaruh komunikasi organisasi, kecerdasan emosi, dan pengambilan keputusan secara parsial maupun bersama-sama terhadap implementasi peran kepemimpinan kepala sekolah dasar se-kecamatan Wonosari. Penelitian ini menggunakan pendekatan kuantitatif dengan jenis penelitian korelasional. Populasi penelitian adalah seluruh kepala sekolah dasar baik negeri maupun swasta di kecamatan Wonosari kabupaten Gunungkidul. Pengumpulan data dilakukan dengan memberikan angket kepada semua kepala sekolah dasar di kecamatan Wonosari. Teknik analisis data yang digunakan adalah regresi linear dan regresi ganda dengan taraf signifikansi 0,05 . Semua pengujian dalam penelitian ini menggunakan bantuan program SPSS versi 17. Hasil penelitian ini menunjukkan bahwa terdapat pengaruh yang positif dan signifikan komunikasi organisasi (adjusted $\mathrm{r}^{2}=48,1 \%$ ), kecerdasan emosi (adjusted $\mathrm{r}^{2}=55,3 \%$ ) dan pengambilan keputusan (adjusted $\mathrm{r}^{2}=63,6 \%$ ) terhadap implementasi peran kepemimpinan kepala sekolah dasar se-kecamatan Wonosari kabupaten Gunungkidul, dan secara bersamasama pengaruhnya (adjusted $\mathrm{R}^{2}$ ) sebesar $66,5 \%$.

Kata Kunci: komunikasi organisasi, kecerdasan emosi, pengambilan keputusan, implementasi peran kepemimpinan

\section{EFFECT OF ORGANIZATIONAL COMMUNICATION, EMOTIONAL INTELLIGENCE AND DECISION ON IMPLEMENTATION OF LEADERSHIP ROLE HEAD ELEMENTARY SCHOOL}

\begin{abstract}
This study aimed to determine the effect of organizational communication, emotional intelligence, and decision making partially or jointly on the implementation of leadership role of the elementary school principals in Wonosari district. This study uses a quantitative approach to the type of correlational research. The study population was all elementary school principals in both public and private in district Wonosari, Gunungkidul. The data was collected by giving questionnaires to all elementary school principals in district Wonosari. The data analysis technique used is linear regression and multiple regression with a significance level of 0.05. All tests in this study used SPSS version 17. The results of this study indicate that there are positive and significant effects between organizational communication (adjusted $r^{2}=48.1 \%$ ), emotional intelligence (adjusted $r^{2}=55.3 \%$ ) and decision making (adjusted $r^{2}=63.6 \%$ ) on the implementation of leadership role of the elementary school principals in Wonosari. The simultaneous influence of those factor is (adjusted $R^{2}$ ) $66.5 \%$.
\end{abstract}

Keywords: organizational communication, emotional intelligence, decision making, implementation of leadership roles. 


\section{Pendahuluan}

Lampiran Peraturan Menteri Pendidikan Nasional nomor 13 tahun 2007 tanggal 17 April 2007 tentang Standar Kepala Sekolah/Madrasah menyebutkan bahwa kompetensi yang harus dimiliki oleh kepala sekolah ada lima hal yaitu kompetensi kepribadian, manajerial, kewirausahaan, supervisi dan sosial. Adanya peraturan tersebut adalah dalam rangka menjadi pedoman dan petunjuk teknis di lapangan agar keberadaan kepala sekolah sebagai pemimpin di lembaga sekolah benar-benar bisa diharapkan untuk merealisasikan tujuan-tujuan pendidikan.

Realita menunjukkan beberapa kepala sekolah bermasalah dalam ketugasan. Merekapun diganti atau dimutasi oleh dinas terkait, sebagaimana salah satunya dikabarkan oleh harian Pelita (4 Juni 2013). Harian itu menyebutkan bahwa di lingkungan Dinas Pendidikan DKI Jakarta sebanyak 143 kepala sekolah SDN dan SMPN yang bermasalah akan diganti. Hal itu dilakukan dalam upaya untuk meningkatkan mutu pendidikan di lingkungan Dinas Pendidikan, Rinciannya 124 kepala SDN dan 19 kepala SMPN, mereka dimutasi karena dianggap telah lalai dalam bertugas.

Kejadian nyata yang terjadi di daerah Gunungkidul khususnya adalah seperti yang diberitakan oleh TRIBUNJOGJA.Com (20 April 2013). Media tersebut memberitakan bahwa seorang oknum kepala sekolah yang diduga sedang bermain judi ditangkap oleh petugas keamanan, padahal yang bersangkutan baru tiga bulan dilantik menjadi kepala sekolah dasar di wilayah tersebut.

Apapun latar belakang kejadian tersebut tentu berdampak luas, baik kepada diri yang bersangkutan, warga sekolah, masyarakat maupun instansi terkait yang menjadi atasannya. Oknum tersebut tidak bisa menyadari posisi dirinya di masyarakat. Oknum tersebut tidak bisa mengendalikan diri dan menjaga kecerdasan emosi untuk tidak berperilaku yang me- langgar norma hukum dan norma masyarakat.

Harian Antara (18 Juli 2011) memuat bahwa Komisi IV DPRD Kota Cimahi, Jawa Barat memanggil 10 kepala sekolah bermasalah yang ada di kota itu karena mereka melakukan pungutan dalam penerimaan peserta didik baru (PPDB). Hal itu terjadi karena para kepala sekolah tersebut melanggar peraturan yang telah ditetapkan oleh atasannya. Dengan kata lain, pengambilan keputusan yang diambil oleh pemimpin tersebut tidak menghiraukan peraturan yang ada di atasnya.

Berdasar pada latar belakang permasalahan, penelitian ini membahas permasalahan: sebagian kepala sekolah masih belum memahami dan melaksanakan halhal yang mempengaruhi dalam implementasi peran kepemimpinan dengan baik. Rumusan masalah dalam penelitian ini yaitu: seberapa besar pengaruh komunikasi organisasi, kecerdasan emosi dan pengambilan keputusan terhadap implementasi peran kepemimpinan kepala sekolah dasar baik secara terpisah maupun secara bersama-sama?

Penelitian ini bertujuan mengetahui pengaruh komunikasi organisasi, kecerdasan emosi dan pengambilan keputusan terhadap implementasi peran kepemimpinan kepala sekolah dasar baik secara parsial maupun secara bersama-sama.

Hasil penelitian ini bisa menjadi; 1) masukan dalam rangka pembinaan dan pengembangan menuju efektifitas kepemimpinan kepala sekolah. 2) menjadi acuan sekaligus masukan dalam berkomunikasi, penerapan kecerdasan emosi dan dalam mengambil keputusan di sekolah untuk mewujudkan efektifitas kepemimpinan kepala sekolah. 3) menjadi bahan evaluasi kepala sekolah akan perjalanan kepemimpinannya selama ini, sehingga bisa mengidentifikasi keefektifan diri. 4) menjadi salah satu khasanah rujukan kepustakaan dalam dunia pendidikan dan secara khusus dalam kepemimpinan kepala sekolah dasar. 
Implementasi Peran Kepemimpinan Kepala Sekolah

Kepemimpinan selalu memiliki peran dalam sebuah organisasi. Hidup dan matinya sebuah organisasi selalu berkaitan sejauh mana peran kepemimpinan dilaksanakan oleh para pemimpinnya. Peran pemimpin sangat dominan dalam sebuah organisasi. Dubrin, Dalglish \& Miller (2006: 9) berpendapat, memimpin adalah kegiatan yang kompleks, sehingga tidak mengherankan bahwa para peneliti mengidentifikasi sembilan peran yang dapat digolongkan sebagai bagian dari fungsi kepemimpinan manajemen.

Sembilan peran yang bisa dilakukan oleh seorang pemimpin secara umum (Dubrin \& Dalglish \& Miller, 2006, pp.1112) yaitu sebagai figurehead (tiruan figur organisasi), spokesperson (juru biacara), negotiator (penegoisasi), coach (pelatih), team builder (pembangun tim), team player (salah satu pemain tim), technical problem solver (pemberi jalan keluar), entrepreneur (pengusaha), dan strategic planner (perancang strategi).

Kepala sekolah (Lunenburg \& Ornstein, 2000, pp.329-334) setidaknya memiliki tiga peran, yaitu leadership role (peran kepemimpinan), managerial role (peran manajerial) dan curriculum-instructional role (peran pelaksana kurikulum pembelajaran). Peran kepemimpinan bagi kepala sekolah merupakan peran yang dominan karena posisinya sebagai pemimpin.

Para pemimpin sekolah harus memanfaatkan berbagai keterampilan, teori, pengetahuan, nilai-nilai, dan disposisi untuk menjadi efektif di sekolah yang kompleks saat ini. Hal ini dibuktikan dengan berbagai kegiatan seorang pemimpin sekolah terlibat dalam berbagai kegiatan setiap hari. Pemimpin menghadapi tugas membantu siswa meningkatkan basis pengetahuan mereka sambil membangun sistem sekolah. Pemimpin sekolah harus meningkatkan kondisi yang kondusif untuk belajar dan ini menuntut bahwa semua pemimpin sekolah harus memiliki pengetahuan dan kemampuan untuk menerap- kan prinsip-prinsip dan informasi mereka (Hancock (2008, p.18).

Peran kepala sekolah (Wahjosumidjo, 1999, p.84) bisa dibagi dalam lima hal, yaitu sebagai pejabat formal, sebagai manajer, sebagai pemimpin, sebagai pendidik, dan sebagai staff. Peran-peran tersebut seharusnya selalu melekat dalam diri seorang kepala sekolah, agar yang bersangkutan bisa menjadi kepala sekolah yang sempurna. Semakin bagus peran kepala sekolah bisa diperankan maka akan memudahkan sekolah dalam melaksanakan pembelajaran secara khusus dan mencapai tujuan-tujuan sekolah secara umum.

Kepala sekolah (Lunenburg \& Ornstein, 2000, p.331) bisa diibaratkan seperti coxswain (pengemudi pacuan dayung), dia memberikan perintah kepada delapan pendayung ke barisan pasukannya secara bersamaan, maju atau mundur, lebih cepat atau lebih lambat, ke kiri dan ke kanan. Kepala sekolah harus mempelajari bagaimana berurusan dengan delapan kelompok orang yang berbeda, seperti delapan pendayung, yang berbaris dalam sebuah kesatuan, sebuah upaya kohesif atau kesatuan yang hebat. Delapan kelompok orang itu adalah: (1) pengawas dan administrasi pusat; (2) dewan sekolah; (3) teman sejawat; (4) orang tua; (5) warga masyarakat; (6) guru; (7) siswa; dan (8) kelompok eksternal seperti dosen, konsultan, lembaga akreditasi, dan kelompok pemerhati pendidikan di tingkat propinsi, kabupaten, kecamatan bahkan gugus. Dengan demikian seorang kepala sekolah dalam peran kepemimpinannya harus bisa menjalin hubungan, kerjasama yang harmonis dengan delapan kelompok orang tersebut di atas. Peran-peran kepemimpinan yang dikemukakan oleh Lunenburg dan Orstein inilah yang diuji dalam penelitian ini.

\section{Komunikasi Organisasi}

Organisasi (Wahjosumidjo, 1999, p.59$60)$ adalah satu kebersamaan dan interaksi serta saling ketergantungan individu-individu yang bekerja ke arah tujuan yang bersifat umum dan hubungan kerja samanya 
telah diatur sesuai dengan struktur yang telah ditentukan. Organisasi adalah kumpulan orang-orang yang bekerja bersama melalui pembagian tenaga kerja untuk mencapai tujuan yang bersifat umum.

Gouran, Miller \& Wiethoff (1995, p.6) mendefinisikan komunikasi sebagai: "Communication is as the purposeful production and transmission of a message by a person to one or more other persons". Muhammad (2005, pp.65-66) mengutip pendapat beberapa ahli mengenai definisi komunikasi organisasi, antara lain, menurut Redding \& Sanborn adalah pengiriman dan penerimaan informasi dalam organisasi yang kompleks. Menurut Katz \& Kahn adalah arus informasi, pertukaran informasi dan pemindahan arti di dalam suatu organisasi. Menurut Zelko \& Dance, suatu sistem terbuka yang saling tergantung yang mencakup komunikasi internal dan komunikasi eksternal. Menurut Thayer adalah arus data yang akan melayani komunikasi organisasi dan proses interkomunikasi dalam beberapa cara.

Komunikasi organisasi (Pace \& Faules, 2000, p.31) merupakan pertunjukan dan penafsiran pesan di antara unit-unit komunikasi yang merupakan bagian dari suatu organisasi tertentu. Dari pendapat ini bisa dipahami bahwa apa yang dikomunikasikan dan bagaimana ditanggapi suatu informasi atau komunikasi itulah yang akan membentuk jaringan komunikasi dalam organisasi.

Komunikasi yang efektif (Mulyana, 2008, p.149) merupakan bentuk kolaborasi atau perpaduan antara sisi-sisi positif komunikasi konteks tinggi dan komunikasi konteks rendah. Komunikasi efektif lebih mencerminkan ketulusan, keterbukaan, kejernihan, keterus-terangan, kesederhanaan dan kesantunan dalam berbicara. Komunikasi efektif bukan suatu komunikasi yang pesan-pesannya penuh menyakitkan orang lain.

\section{Arah Aliran Komunikasi Organisasi}

Komunikasi organisasi pasti akan dilakukan oleh setiap kepala sekolah dalam mengimplementasikan peran kepemimpin- annya di sekolah. Komunikasi harus dijalankan kepada siapa saja yang berkepentingan secara langsung maupun secara tidak langsung untuk mewujudkan tujuan sekolah. Tujuan komunikasi organisasi adalah untuk menyediakan sarana transmisi informasi penting untuk pencapaian tujuan. Hal ini seperti yang diungkapkan oleh Lunenburg \& Ornstein (2000, p.185): "The purpose of organizational communication is to provide the means for transmitting information essential to goal achievement."

Arah aliran komunikasi organisasi menurut Lunenburg \& Ornstein (2000, p. 185), "Much of this communication flow is carried in four distinct directions: downward, upward, horizontally, and diagonally. The other major communication flow is the grapevine." Arah aliran komunikasi (Muhammad, 2005, p.107) itu hanya ada dua yaitu jaringan komunikasi formal dan jaringan komunikasi informal. Jaringan komunikasi formal meliputi komunikasi ke bawah, komunikasi ke atas dan komunikasi horizontal. Sedangkan menurut Pace \& Faules (2000, pp.183-184) arah aliran informasi dibagi dalam komunikasi ke bawah, komunikasi ke atas, komunikasi horizontal, komunikasi lintas saluran dan selentingan. Dalam penelitian ini pendapat Pace dan Faules dianggap lebih tepat dipakai untuk menguji apakah komunikasi organisasi memiliki pengaruh terhadap implementasi kepemimpinan kepala sekolah dasar.

Griffin (2004, p.106) menyatakan “ ... Beragam peran yang harus dijalankan oleh seorang manajer atau pemimpin mustahil bisa diwujudkan tanpa komunikasi". Hakikat berorganisasi sangat tergantung pada bagaimana personal yang ada dalam organisasi tersebut berkomunikasi. Semakin baik kualitas komunikasi maka akan semakin baik kualitas organisasi tersebut.

Demikian pula yang dinyatakan oleh Pace \& Faules (2000, p.24) bahwa, memperbaiki komunikasi organisasi berarti memperbaiki organisasi, karena tujuan utama mempelajari komunikasi adalah memperbaiki organisasi. Dengan kata lain, orang mempelajari komunikasi organisasi untuk menjadi manajer yang lebih baik. 


\section{Kecerdasan Emosi}

Meyer \& Salovey (Shahhosseini, Silong \& Ismail, 2013, p.2) menyebutkan kecerdasan emosional adalah Kecerdasan emosional adalah kemampuan untuk memahami emosi, untuk mengakses dan menghasilkan emosi sehingga membantu berpikir, untuk memahami emosi dan pengetahuan emosional, dan reflektif mengatur emosi sehingga dapat meningkatkan pertumbuhan emosi dan intelektual.

Orang-orang yang memiliki tingkat kecerdasan emosi yang tinggi tidak hanya lebih sukses dalam karier, tetapi mereka juga lebih sehat, bahagia, dan menikmati hubungan yang lebih baik dengan orang lain. Mereka dengan tingkat kecerdasan emosi yang tinggi cenderung mengalami keseimbangan yang sehat dari perasaan seperti: motivasi, persahabatan, fokus, kenyamanan, kedamaian, kesadaran, kecukupan, kontrol diri, kebebasan, otonomi, kepuasan, apresiasi, koneksi. Hal ini sebagaimana ditulis McPheat (2010, p.11), "It has been found that not only are people with a high level of EI more succesfull in their careers, but they also are healthier, happier, and enjoy better relationships with others."

McPheat (2010, p.22) membagi model kecerdasan emosi menjadi tiga, " ... there are three main models: the ability EI, the Trait EI model, and the mixed model". KE/EQ berperan sebagai mesin giling/ prime mover kecerdasan manusia secara utuh karena berkait dengan integritas dan keunggulan pribadi seorang pemimpin yang harus dikembangkan sejak dini dalam lingkungan keluarga, sekolah dan tempat kerja secara menyeluruh dan berkesinambungan (Winarno \& Saksono, 2001, p.20).

Orang-orang berteori bahwa kecerdasan emosi memberikan kontribusi yang besar terhadap kemampuan orang untuk bekerja secara efektif dalam tim, mengelola stres, dan/atau memimpin orang lain (Rossete \& Ciarrochi, 2005, p.5).

\section{Pengambilan Keputusan}

Pengambilan keputusan adalah proses memilih beberapa alternatif, sesuatu yang penting untuk memahami administrasi pendidikan karena proses pemilihan alternatif tersebut memainkan peran penting dalam memotivasi, peran kepemimpinan, berkomunikasi, dan terkait dengan perubahan organisasi (Lunenburg \& Ornstein, 2000, p.155). Setiap pengambilan keputusan akan mendukung semua fungsi manajemen yang terdiri dari perencanaan, pengorganisasian, penyusunan, memimpin dan pengawasan (Dharmesta, 1996, p.60).

Ada beberapa langkah dalam pengambilan keputusan yang bisa dilakukan yaitu: (1) mendaftar semua alternatif yang tersedia yang harus dipertimbangkan dalam keputusan; (2) harus mendaftar peristiwa yang mungkin terjadi; (3) membuat tabel hasil kemungkinan kombinasi alternatif keputusan dan unsur mutlak (Levin et al., 1995, 98).

Menurut Griffin (1990, p.131) langkah-langkah dalam pengambilan keputusan yang rasional adalah: (1) mengenali dan mendefinisikan situasi keputusan; (2) mengidentifikasikan alternatif; (3) mengevaluasi alternatif; (4) memilih alternatif terbaik; (5) mengimplementasikan alternatif yang terpilih; (6) mengikuti dan mengevaluasi hasil.

Semua keputusan, bagaimanapun, memiliki pengaruh, baik besar atau kecil, pada kinerja. Oleh karena itu, sangat penting bagi manajer untuk meningkatkan kemampuan keterampilan pengambilan keputusan. Kualitas keputusan yang mereka capai menjadi tolok ukur efektivitas dan nilai mereka bagi organisasi. Suka atau tidak, manajer dievaluasi dan dihargai atas dasar pentingnya, banyaknya, dan kualitas hasil dari keputusan mereka (Donnelly, Gibson \& Ivancevich, 1990, p.535).

\section{Metode Penelitian}

Jenis Penelitian

Penelitian ini menggunakan pendekatan kuantitatif dengan jenis penelitian korelasional. Tujuan penelitian ini untuk menggeneralisasikan populasi yang diteliti. 


\section{Waktu dan Tempat Penelitian}

Penelitian dilakukan di sekolah-sekolah dasar baik negeri maupun swasta di wilayah kerja UPT (Unit Pelaksana Teknis) TK dan SD Dinas Pendidikan Pemuda Dan Olahraga di Kecamatan Wonosari Kabupaten Gunungkidul. Penelitian dilaksanakan mulai bulan September 2013 sampai dengan bulan Nopember tahun 2013.

\section{Populasi dan Sampel}

Populasi penilitian ini meliputi seluruh kepala sekolah di sekolah-sekolah dasar baik negeri maupun swasta di wilayah kerja UPT (Unit Pelaksana Teknis) TK dan SD Dinas Pendidikan Pemuda Dan Olahraga di Kecamatan Wonosari Kabupaten Gunungkidul. Jumlah sekolah dasar negeri dan swasta di Kecamatan Wonosari ada 44 sekolah. Seluruh kepala sekolah dasar tersebut akan diteliti, sehingga penelitian ini merupakan studi populasi.

\section{Teknik Analisis Data \\ Uji Hipotesis Penelitian}

Regresi linear sederhana digunakan untuk mengetahui apakah masing-masing variabel bebas $\left(X_{1}, X_{2}, X_{3}\right)$ secara terpisah berpengaruh terhadap variabel terikat $(\mathrm{Y})$ dengan persamaan sebagai berikut.

$\hat{Y}=a+\mathrm{bX}$

Dalam regresi sederhana (Field, 2009, p.207) di antaranya diketahui: (1) seberapa besar hubungan antara variabel bebas terhadap variabel terikat, yang bisa dilihat dalam output SPSS, model summary pada kolom R; (2) seberapa besar pengaruh variabel bebas terhadap variabel terikat, yang ditunjukkan pada kolom $r$ Square $\left(\mathrm{r}^{2}\right)$ dan adjusted $\mathrm{r}^{2}$; (3) pada output SPSS bagian ANOVA kolom Sig yang menunjukkan seberapa tingkat signifikan keberpengaruhan predictor; (4) pada output SPSS bagian Coeffisients kolom B menunjukkan besarnya Constanta yang memiliki arti seberapa besar kemampaun atau nilai variabel terikat ketika tidak ada pengaruh sama sekali dari variabel bebas. Dalam bagian koefisien ini juga dijadikan patokan untuk uji hipotesis secara parsial, yaitu masing-masing variabel bebas apakah memiliki pengaruh yang positif terhadap variabel terikat.

Regresi ganda digunakan untuk mengetahui apakah secara bersama-sama variabel bebas $\left(X_{1}, X_{2}, X_{3}\right)$ berpengaruh terhadap variabel terikat $(Y)$. Bentuk persamaan garis regresi gandanya (Field, 2009: 210) adalah sebagai berikut.

$\hat{Y}=a+b_{1} X_{1}+b_{2} X_{2}+b_{3} X_{3}$.

Regresi ganda (multiple regression) menunjukkan; (1) seberapa besar hubungan predictors (beberapa variabel bebas) atau sering disebut sebagai multiple correlation coefficient yang disimbulkan dengan multiple $\mathrm{R}$, artinya seberapa besar hubungan dari be-berapa variabel bebas terhadap variabel terikat. Semakin besar nilai multiple $\mathrm{R}$ maka semakin besar hubungan antara variabel bebas terhadap variabel terikat (Field, 2009, p.211); (2) Seberapa besar pengaruh variabel bebas terhadap variabel terikat, yang ditunjukkan oleh $\mathrm{r}$ Square $\left(\mathrm{r}^{2}\right)$ dan adjusted $\mathrm{r}^{2}$. ANOVA kolom Sig menunjukkan seberapa tingkat signifikan keberpengaruhan predictor. Dalam bagian ANOVA ini juga dijadikan patokan untuk uji hipotesis secara bersama-sama, yaitu semua variabel bebas secara bersamasama apakah memiliki pengaruh yang positif terhadap variabel terikat. Pada output SPSS bagian Coeffisients kolom B yang menunjukkan besarnya Constant yang memiliki arti seberapa besar kemampaun atau nilai variabel terikat ketika tidak ada pengaruh sama sekali dari semua variabel bebas.

\section{Hasil Penelitian dan Pembahasan}

Analisis hipotesis pertama: Terdapat pengaruh yang positif dan signifikan antara komunikasi organisasi terhadap implementasi peran kepemimpinan kepala sekolah dasar di kecamatan Wonosari. Dari hasil olah data SPSS versi 17 pada analisis regresi didapatkan Model Summary bahwa r sebesar 0,703. Angka tersebut menunjukkan bahwa antara komunikasi organisasi dengan implementasi peran kepemimpinan kepala sekolah dasar terdapat hubung- 
an yang kuat, atau bila dipresentase maka hubungan tersebut adalah sebesar 70,3\%.

Adapun $\mathrm{r}^{2}$ atau $\mathrm{r}$ determinasi menunjukkan angka 0,494. Hal tersebut menunjukkan pengertian bahwa implementasi peran kepemimpinan kepala sekolah dasar dipengaruhi oleh variabel komunikasi organisasi sebesar 49,4\%. Sedangkan adjusted $\mathrm{r}^{2}$ menunjukkan 0,481 yang berarti variabel komunikasi organisasi mampu menjelaskan pengaruhnya terhadap implementasi peran kepemimpinan kepala sekolah dasar sebesar $48,1 \%$ dan sisanya (yaitu 100\% $48,1 \%=51,9 \%$ ) dipengaruhi oleh variabel yang lain yang tidak bisa diterangkan oleh variabel komunikasi organisasi.

Dari uji ANOVA diperoleh data nilai $\mathrm{F}=40,928$ dengan tingkat signifikansi 0,000 . Probabilitas 0,000 jauh lebih kecil dari nilai $\operatorname{Sig}=0,05$. Artinya, variabel komunikasi organisasi signifikan mempengaruhi implementasi peran kepemimpinan kepala sekolah dasar. Dari uji Coefisients didapatkan nilai constant $=36,793$ dan $\mathrm{B}=0,994$ sehingga diperoleh persamaan regresi sederhananya sebagai berikut:

$\hat{Y}=36,793+0,994 X_{1}$

Persamaan tersebut memiliki makna bahwa apabila variabel komunikasi organisasi $\left(X_{1}\right)$ bernilai nol, maka nilai implementasi peran kepemimpinan kepala sekolah dasar bernilai 36,793. Nilai koefisien komunikasi organisasi bernilai 0,994 memiliki makna setiap kenaikan satu satuan komunikasi organisasi akan meningkatkan satu satuan implementasi peran kepemimpinan kepala sekolah dasar, dengan asumsi bahwa variabel bebas yang lain tetap dalam regresinya.

Tabel Coefficients menunjukkan bahwa nilai $t$ sebesar 6,398 dengan tingkat signifikansi 0,000. Dari penjelasan analisis di atas bisa disimpulkan bahwa terbukti komunikasi organisasi berpengaruh secara positif terhadap implementasi peran kepemimpinan kepala sekolah dasar atau bisa dikatakan hipotesis pertama penelitian ini bisa diterima.

Analisis hipotesis kedua: Terdapat pengaruh yang positif dan signifikan antara kecerdasan emosi dengan implemen- tasi peran kepemimpinan kepala sekolah dasar. Dari hasil olah data SPSS versi 17 pada analisis regresi didapatkan Model Summary bahwa r sebesar 0,751. Angka tersebut menunjukkan bahwa antara kecerdasan emosi dengan implementasi peran kepemimpinan kepala sekolah dasar terdapat hubungan yang kuat, atau bila dipersentase maka hubungan tersebut adalah $75,1 \%$.

Adapun $\mathrm{r}^{2}$ atau $\mathrm{r}$ determinasi menunjukkan angka 0,564. Hal tersebut menunjukkan pengertian bahwa implementasi peran kepemimpinan kepala sekolah dasar dipengaruhi oleh kecerdasan emosi sebesar 56,4 \%. Sedangkan adjusted $\mathrm{r}^{2}$ menunjukkan 0,553 yang berarti variabel kecerdasan emosi mampu menjelaskan pengaruhnya terhadap implementasi peran kepemimpinan kepala sekolah dasar sebesar 55,3\% dan sisanya (yaitu 100\% $55,3 \%=44,7 \%$ ) dipengaruhi oleh variabel yang lain yang tidak bisa diterangkan oleh variabel kecerdasan emosi.

Dari uji ANOVA diperoleh data nilai $\mathrm{F}=54,268$ dengan tingkat signifikansi 0,000. Probabilitas 0,000 jauh lebih kecil dari nilai $\operatorname{Sig}=0,05$. Artinya, variabel kecerdasan emosi signifikan mempengaruhi implementasi peran kepemimpinan kepala sekolah dasar. Dari uji Coeffisients didapatkan nilai constant $=10,395$ dan $B=1,025$ sehingga diperoleh persamaan regresi sederhananya sebagai berikut:

$\hat{Y}=10,395+1,025 X$

Persamaan tersebut memiliki makna bahwa apabila variabel kecerdasan emosi $\left(X_{2}\right)$ bernilai nol, maka nilai implementasi peran kepemimpinan kepala sekolah dasar bernilai 10,395. Nilai koefisien kecerdasan emosi bernilai 1,025 memiliki makna setiap kenaikan satu satuan kecerdasan emosi akan meningkatkan satu satuan implementasi peran kepemimpinan kepala sekolah dasar, dengan asumsi bahwa variabel bebas yang lain tetap dalam regresinya. Tabel Coefficients menunjukkan bahwa nilai $t$ sebesar 7,367 dengan signifikansi 0,000. Dari penjelasan analisis di atas bisa disimpulkan bahwa terbukti kecerdasan emosi berpengaruh secara positif terhadap im- 
plementasi peran kepemimpinan kepala sekolah dasar atau hipotesis kedua penelitian ini bisa diterima.

Analisis hipotesis ketiga: terdapat pengaruh yang positif dan signifikan antara pengambilan keputusan dengan implementasi peran kepemimpinan kepala sekolah dasar

Dari hasil olah data SPSS versi 17 pada analisis regresi didapatkan Model Summary bahwa $\mathrm{r}$ menunjukkan angka 0,803 . Angka tersebut menunjukkan bahwa antara pengambilan keputusan dengan implementasi peran kepemimpinan kepala sekolah dasar terdapat hubungan yang sangat kuat, atau bila dipersentase maka hubungan tersebut adalah $80,3 \%$.

Adapun $\mathrm{r}^{2}$ atau $\mathrm{r}$ determinasi menunjukkan angka 0,645. Hal tersebut menunjukkan pengertian bahwa implementasi peran kepemimpinan kepala sekolah dasar dipengaruhi oleh pengambilan keputusan sebesar $64,5 \%$. Sedangkan adjusted $\mathrm{r}^{2}$ menunjukkan 0,636 yang berarti variabel pengambilan keputusan mampu menjelaskan pengaruhnya terhadap implementasi peran kepemimpinan kepala sekolah dasar sebesar $63,6 \%$ dan sisanya (yaitu 100\% $63,6 \%=36,4 \%$ ) dipengaruhi oleh variabel yang lain yang tidak bisa diterangkan oleh variabel pengambilan keputusan.

Dari uji ANOVA diperoleh data nilai $\mathrm{F}=76,230$ dengan tingkat signifikansi 0,000 . Probabilitas 0,000 jauh lebih kecil dari nilai $\operatorname{Sig}=0,05$. Artinya, variabel pengambilan keputusan signifikan memengaruhi implementasi peran kepemimpinan kepala sekolah dasar.

Dari uji Coeffisients didapatkan nilai constant $=16,421$ dan $B=1,633$ sehingga diperoleh persamaan regresi sederhananya sebagai berikut:

$\hat{Y}=16,421+1,633 X_{3}$

Persamaan tersebut memiliki makna bahwa apabila variabel pengambilan keputusan $\left(X_{3}\right)$ bernilai nol, maka nilai implementasi peran kepemimpinan kepala sekolah dasar bernilai 16,421. Nilai koeffisien pengambilan keputusan bernilai 1,633 memiliki makna setiap kenaikan satu satuan pengambilan keputusan akan meningkatkan satu satuan implementasi peran kepemimpinan kepala sekolah dasar, dengan asumsi bahwa variabel bebas yang lain tetap dalam regresinya.

Hipotesis ketiga dalam penelitian ini adalah terdapat pengaruh yang positif dan signifikan antara pengambilan keputusan terhadap implementasi peran kepemimpinan kepala sekolah dasar di kecamatan Wonosari. Tabel Coefficients di atas menunjukkan bahwa nilai t sebesar 8,731 dengan signifikansi 0,000.

Dari penjelasan analisis di atas bisa disimpulkan bahwa terbukti pengambilan keputusan berpengaruh secara positif dan signifikan terhadap implementasi peran kepemimpinan kepala sekolah dasar atau hipotesis ketiga penelitian ini bisa diterima.

Analisis hipotesis keempat: terdapat pengaruh yang positif dan signifikan antara komunikasi organisasi, kecerdasan emosi dan pengambilan keputusan secara bersama-sama terhadap implementasi peran kepemimpinan kepala sekolah dasar.

Dari hasil olah data SPSS versi 17 pada analisis regresi didapatkan Model Summary bahwa $\mathrm{r}$ menunjukkan angka 0,830 . Angka tersebut menunjukkan bahwa antara komunikasi organisasi, kecerdasan emosi dan pengambilan keputusan secara bersama-sama terdapat hubungan yang sangat kuat dengan implementasi peran kepemimpinan kepala sekolah dasar.

Adapun $\mathrm{r}^{2}$ atau $\mathrm{r}$ determinasi menunjukkan angka 0,689. Hal tersebut menunjukkan pengertian bahwa implementasi peran kepemimpinan kepala sekolah dasar dipengaruhi oleh komunikasi organisasi, kecerdasan emosi dan pengambilan keputusan secara bersama-sama sebesar $68,9 \%$. Sedangkan adjusted $\mathrm{r}^{2}$ menunjukkan 0,665 yang berarti variabel pengambilan keputusan mampu menjelaskan pengaruhnya terhadap implementasi peran kepemimpinan kepala sekolah dasar sebesar $66,5 \%$ dan sisanya (yaitu 100\% - 66,5\% = $33,5 \%$ ) dipengaruhi oleh variabel yang lain yang tidak bisa dijelaskan oleh ketiga variabel tersebut.

Hipotesis keempat dalam penelitian ini adalah terdapat pengaruh yang positif 
dan signifikan antara komunikasi organisasi, kecerdasan emosi, dan pengambilan keputusan secara bersama-sama terhadap implementasi peran kepemimpinan kepala sekolah dasar di kecamatan Wonosari. Dari uji ANOVA diperoleh data nilai $\mathrm{F}=29,514$ dengan tingkat signifikansi 0,000. Probabilitas 0,000 jauh lebih kecil dari nilai Sig = 0,05 . Oleh karena itu komunikasi organisasi, kecerdasan emosi dan pengambilan keputusan secara bersama-sama bisa dipakai untuk memprediksi tingkat implementasi peran kepemimpinan kepala sekolah dasar.

Dari uji Coeffisients didapatkan nilai constant $=8,856$ dan $\mathrm{B}=0,265,0,233$, dan 1,087 sehingga diperoleh persamaan regresi gandanya sebagai berikut:

$\hat{Y}=8,856+0,265 X_{1}+0,233 X_{2}+1,087 X_{3}$

Persamaan tersebut memiliki makna bahwa apabila variabel $X_{1,2,3}$ bernilai nol, maka nilai implementasi peran kepemimpinan kepala sekolah dasar bernilai 8,856. Nilai koefisien komunikasi organisasi bernilai 0,265 , kecerdasan emosi bernilai 0,233 dan pengambilan keputusan bernilai 1,087 memiliki makna setiap kenaikan satu satuan ketiga variabel tersebut akan meningkatkan satu satuan implementasi peran kepemimpinan kepala sekolah dasar, dengan asumsi bahwa variabel bebas yang lain tetap dalam regresinya. Dari penjelasan analisis di atas bisa disimpulkan bahwa terbukti komunikasi organisasi, kecerdasan emosi dan pengambilan keputusan secara bersama-sama berpengaruh secara positif terhadap implementasi peran kepemimpinan kepala sekolah dasar atau hipotesis keempat penelitian ini bisa diterima.

Pembahasan

Hasil penelitian ini, komunikasi organisasi yang dilakukan oleh kepala sekolah dasar se kecamatan Wonosari menunjukkan dalam kategori cukup baik dan sangat baik. Hal tersebut didasarkan pada hasil angket terhadap 44 orang kepala sekolah yang memperoleh skor variabel komunikasi organisasi sebesar 2328 dari jumlah ideal yang diharapkan 2816.

Komunikasi organisasi benar-benar memiliki pengaruh yang positif dan signi- fikan terhadap implementasi peran kepemimpinan kepala sekolah dasar. Dalam penelitian ini pengaruh itu ditunjukkan secara nyata dalam adjusted $\mathrm{r}^{2}$ sebesar $48,1 \%$, sebuah pengaruh yang cukup kuat. Oleh karena itu kepala sekolah DASAR memiliki kebutuhan untuk selalu menjaga dan meningkatkan kemampuan komunikasi organisasi terhadap pihak-pihak yang berkepentingan terhadap kepemimpinan dan sekolahnya baik secara langsung maupun secara tidak langsung. Kegiatankegiatan atau pelatihan-pelatihan yang mendukung peningkatan kemampuan berkomunikasi akan mendukung dan meningkatkan kemampuan kepala sekolah dasar dalam mengimplementasikan peran kepemimpinan di sekolah.

Pengaruh Kecerdasan Emosi terhadap Implementasi Peran Kepemimpinan Kepala Sekolah Dasar

Dalam penelitian ini, dari 44 kepala sekolah dasar se-kecamatan Wonosari menunjukkan bahwa kecerdasan emosi mereka masuk dalam kategori yang cukup baik dan sangat baik, dengan perolehan skor sebesar 3390 dari jumlah ideal yang diharapkan 3696. Karena pengaruh kecerdasan emosi yang sangat nyata dalam implementasi peran kepemimpinan kepala sekolah dasar, maka setiap kepala sekolah berkepentingan untuk memilik dan menerapkannya di dalam kepemimpinannya di sekolah. Dalam penelitian ini pengaruh itu ditunjukkan secara nyata dalam adjusted $\mathrm{r}^{2}$ sebesar 48,1\%, sebuah pengaruh yang cukup kuat. Kecerdasan emosi akan mengantarkan kepala sekolah menjadi pemimpin yang sangat berpengaruh dan berkesan pada anak buahnya maupun masyarakat.

Pengaruh Pengambilan Keputusan

Terhadap Implementasi Peran

Kepemimpinan Kepala Sekolah dasar

Dalam penelitian ini, dari 44 kepala sekolah dasar se kecamatan Wonosari menunjukkan bahwa pengambilam keputusan yang dilaksanakan oleh mereka termasuk dalam kategori yang cukup baik dan sa- 
ngat baik. Hal tersebut terbukti dari hasil analisis data yang menunjukkan perolehan skor pengambilan keputusan sebesar 1966 dari jumlah ideal yang diharapkan yaitu 2288.

Pengaruh pengambilan keputusan terhadap implementasi peran kepemimpinan kepala sekolah dasar, sebagaimana dijelaskan dalam analisis regresi adjusted $\mathrm{R}^{2}$ yaitu sebesar $63,6 \%$, sebuah pengaruh yang termasuk cukup kuat, positif dan signifikan. Hal tersebut menunjukkan bahwa semakin bagus pengambilan keputusan dilakukan akan semakin meningkatkan tingkat implementasi peran kepemimpinan kepala sekolah dasar di kecamatan Wonosari.

Hal-hal yang berkenaan dengan peningkatan ketrampilan dan ketepatan strategi dalam pengambilan keputusan di sekolah harus dilaksanakan. Kepala sekolah dasar harus terus belajar dari pengalaman dan memberikan contoh yang baik bagi anak buah tentang bagaimana keputusan itu menjadi miliki bersama dan sekaligus menjadi tanggungjawab bersama dalam pelaksanaannya.

Pengaruh Komunikasi Organisasi, Kecerdasan Emosi, dan Pengambilan Keputusan secara Bersama-sama terhadap Implementasi Peran Kepemimpinan Kepala Sekolah Dasar

Sebagaimana dijelaskan dalam poinpoin tersebut di atas, secara parsial komunikasi organisasi, kecerdasan emosi dan pengambilan keputusan memiliki pengaruh yang nyata, positif dan signifikan terhadap implementasi kepemimpinan kepala sekolah dasar. Kemampuan-kemampuan tersebut secara bersama-sama telah dilakukan oleh kepala sekolah dasar di kecamatan Wonosari berdasarkan angket yang diberikan kepada 44 orang kepala sekolah, termasuk dalam kategori cukup baik dan sangat baik, yaitu mendapat skor 3933 dari jumlah ideal yang diharapkan yaitu 4400 . Selain faktor-faktor yang lain, ketiga variabel yaitu komunikasi organisasi, kecerdasan emosi dan pengambilan keputusan, secara statistik memiliki pengaruh dalam adjusted $\mathrm{R}^{2}$ sebesar $66,5 \%$, sebuah pengaruh yang cukup kuat.

Kepala sekolah dasar sebagai pelaksana maupun sebagai pemimpin di level sekolah dasar perlu mendapat dukungan, dorongan dan pendampingan secara maksimal agar mereka benar-benar bisa menjalankan perannya dengan maksimal. Dukungan dan dorongan serta pendampingan tersebut ditindaklanjuti dengan pengawasan yang humanis.

\section{Simpulan dan Saran}

Komunikasi organisasi yang dijalankan oleh kepala sekolah dasar memiliki pengaruh positif dan signifikan terhadap implementasi peran kepemimpinan. Komunkasi organisasi memiliki pengaruh terhadap implementasi peran kepemimpinan kepala sekolah secara parsial sebesar $48,1 \%$.

Kecerdasan emosi yang dimiliki dan direalisasikan oleh kepala sekolah dasar memiliki pengaruh yang positif dan signifikan terhadap implementasi peran kepemimpinan. Kecerdasan emosi memiliki pengaruh terhadap implementasi peran kepemimpinan kepala sekolah secara parsial sebesar 55,3\%.

Pengambilan keputusan yang dijalankan dan direalisasikan oleh kepala sekolah dasar memiliki pengaruh yang positif dan signifikan terhadap implementasi peran kepemimpinan. Pengambilan keputusan memiliki pengaruh terhadap implementasi peran kepemimpinan kepala sekolah secara parsial sebesar 63,6\%.

Komunikasi organisasi, kecerdasan emosi dan pengambilan keputusan secara bersama-sama memiliki pengaruh yang positif dan signifikan terhadap implementasi peran kepemimpinan kepala sekolah dasar. Secara bersama-sama pengaruh ketiga variabel tersebut terhadap implementasi peran kepemimpinan kepala sekolah dasar adalah $66,5 \%$.

Implikasi

Berdasarkan hasil penelitian ini bahwa komunikasi organisasi, kecerdas- 
an emosi, dan pengambilan keputusan secara parsial maupun bersama-sama memiliki pengaruh yang positif dan signifikan terhadap implementasi peran kepemimpinan kepala sekolah dasar. Kepala sekolah mestinya benar-benar memperhatikan ketiga faktor tersebut di samping hal-hal lain yang berpengaruh dalam implementasi peran kepemimpinannya.

\section{Keterbatasan Penelitian}

Penelitian ini telah dilaksanakan dengan usaha semaksimal mungkin. Sekalipun demikian, disadari bahwa dalam penelitian ini masih didapatkan beberapa kekurangan atau keterbatasan, antara lain: Manfaat dari penelitian ini tidak bisa dirasakan secara langsung oleh masyarakat, masih memerlukan proses dan tindak lanjut. Untuk mencapai rekomendasi dari penelitian ini masih memerlukan upaya lanjutan dan dalam waktu yang tidak singkat. Dari sisi wilayah kerja penelitian ini hanya dibatasi pada kepala sekolah dasar di kecamatan Wonosari kabupaten Gunungkidul dan cara mendapat informasi hanya dibatasi pada kepala sekolah dasar. Cara menggali informasi dan data tentang pelaksanaan atau perilaku komunikasi organisasi, kecerdasan emosi, pengambilan keputusan dan implementasi peran kepemimpinan kepala sekolah dasar dalam penelitian ini hanya dibatasi dengan angket saja, sehingga beberapa informasi tentang kepala sekolah yang bersifat kualitatif harus direduksi.

\section{Saran}

Berdasarkan temuan hasil penelitian ini, maka perlu disampaikan beberapa saran antara lain: untuk penentu kebijakan, hendaknya frekuensi pelatihan atau penataran tentang komunikasi organisasi, kecerdasan emosi dan pengambilan keputusan menjadi perhatian yang serius, mengingat pengaruh ketiga hal tersebut dalam mendorong kepala sekolah dalam mengimplementasikan peran kepemimpinannya di sekolah. Memberikan fasilitas yang memadai terhadap kepala sekolah dasar guna meningkatkan implementasi peran kepemimpinannya, baik berupa pendampingan, pertemuan, atau bimbingan secara terus menerus sehingga kepala sekolah benarbenar memiliki perhatian yang bagus terhadap peran kepemimpinan demi mensukseskan pendidikan.

Untuk kepala sekolah dasar, perlu memperhatikan arah komunikasi yang dilakukan, tidak hanya fokus pada pihakpihak tertentu yang berkepentingan secara langsung saja. Sekalipun rumit, hendaknya komunikasi dengan berbagai pihak, terutama bawahan harus dilakukan dengan baik dan berarti. Perlu membiasakan perilaku-perilaku yang mencerminkan emosi yang cerdas, karena hal tersebut berpengaruh positif terhadap diri sendiri maupun anak buah. Selain pembiasaan terhadap diri sendiri juga perlu membelajarkan kecerdasan emosi pada anak buah. Kecerdasan emosi dalam kepemimpinan akan membuahkan kekuatan diri dalam kepemimpinan. Hendaknya prosedur pengambilan keputusan dijalankan sebagaimana mestinya, agar bisa membuahkan hasil keputusan yang prima dan meningkatkan kualitas implementasi peran kepemimpinan. Pengambilan keputusan yang tepat akan meningkatkan pencapaian tujuan pendidikan.

\section{Daftar Pustaka}

Anonim. (2013). 143 Kepala Sekolah Bermasalah di DKI Jakarta Diganti. Diakses pada tanggal 4 Juni 2103 dari http://www.pelita.or.id/baca.php? id $=56533$.

Bu'tu, D. (2011). Peranan kepemimpinan kepala sekolah dalam meningkatkan kinerja guru di smp negeri sentani kabupaten jayapura. Tesis magister, tidak diterbitkan, Universitas $\mathrm{Ne}$ geri Yogyakarta.

Dharmesta, B.S. (1996). Azas-azas manajemen modern. Yogyakarta: Liberty. Dewan akan memanggil 10 kepala sekolah bermasalah. (2011, 18 Juli). Antara. 
Dubrin, A.J, Dalglish, C \& Miller, P. (2006). Leadership. Australia: Wiley.

Fiedler, F.E. A. (1967) Theory of leadership effectiveness. Urbana: McGraw-Hill.

Field, D. (2005). Discovering statistic using SPSS. London: Sage publications LTD

Gouran, D.S, Miller, L.D \& Wiethoff, W.E. (1995). Mastering communication. Washington: Allyn and Bacon.

Griffin, R.W. (1990). Management $3^{\text {rd }}$ edition. Boston: Houghton mifflin company.

(2004). Manajemen jilid $1 \mathcal{E} 2$. (terjemahan oleh Gina Gania, buku asli terbit tahun 2002). Jakarta: Erlangga.

Hancock, G.R. (2008). School leadership: a study investigating howemergent formal school leaders understand and collaborate with informal leaders to develop a better understanding of the terrain they are entering. A dissertation. Pennsylvania: ProQuest LLC.

Kemdiknas. (2007). Peraturan menteri pendidikan nasional nomor 13 tahun 2007, tentang standar kepala sekolah/ madrasah.

Levin, R.I, et al. (1989). Pengambilan keputusan secara kuantitatif (terjemahan oleh Nartanto). Jakarta: Raja grafindo persada.

Lunenburg, F.C \& Ornstein, A.C. (2000). Educational administration. Belmont: Wadsworth.

Muhammad, A. (2005). Komunikasi organisasi. Jakarta: Bumi aksara.
Mulyana, D. (2008). Komunikasi efektif. Bandung: Remaja rosda karya.

HAS. (2013). Oknum kepsek judi, disdikpora gunungkidul bentuk tim gabungan. Diaskes pada 20 April 2013 dari http://jogja.tribunnews.com/2013/ 04/20/oknum-kepsek-judidisdikpora-gunungkidul-bentuktim-gabungan/

Pace, R.W \& Faules, D.F. (2000). Komunikasi organisasi. (terjemahan Deddy Mulyana). Bandung: Remaja rosdakarya.

Rossete, D \& Ciarrochi, J. (2005). EI and its relationship to workplace performance outcomes of leadership effectiveness. Leadership organizational development, 26, 388-399. Versi elektronik. Diunduh tanggal 15 April 2013. Wollongong.

Shahhosseini, M, Silong, A.D, \& Ismaill, I.A. (2013). Relationship between transactional, transformational leadership styles, emotional intelligence and job performance. International refereed research journal, IV, 1522.

Simon, H.A. (2007). Administrative behavior. (terjemahan oleh St. Dianjung, buku asli terbit tahun 1990). Jakarta: Bumi aksara.

Winarno, A \& Saksono, T. (2001). Kecerdasan emosi, bahan ajar diklatpim tingkat IV. Jakarta: lembaga administrasi negara-RI.

Wahjosumidjo. (1999). Kepemimpinan kepala sekolah tinjauan teoritik dan permasalahannya. Jakarta: Raja Grafindo Persada. 